\title{
Hvorfor har små kommuner færre overliggere?
}

Små kommuner i Østfold har kortere pasientlister hos fastlegen og flere korttidsplasser i sykehjem. I tillegg samarbeider fastlegene bedre med hjemmetjenesten.

\section{Forfattere}

\author{
Hans Knut Otterstad \\ Spesialist i samfunnsmedisin og helsetjenesteforsker
}

\section{Nøkkelord}

Samhandlingsreformen

Sykepleien 2017 105(2)(56-59)

DOI: https://doi.org/10.4220/Sykepleiens.2017.60451

\section{HOVEDBUDSKAP}

Etter tre år med samhandlingsreformen viser statistikk fra Østfold et tydelig mønster: Forekomsten av overliggere i sykehus øker med kommunestørrelse. Det synes å være tre årsaker: Små kommuner har bedre dekning av korttidsplasser i sykehjem. Videre er fastlegenes gjennomsnittlige listelengde betydelig kortere i små kommuner. I små kommuner er legesentrene mindre og vanligvis lokalisert nær hjemmesykepleien og andre kommunale tjenestetilbud, noe som fremmer samhandlingen om felles pasienter.

To viktige reformer har blitt iverksatt etter tusenårsskiftet:

fastlegeordningen fra 2001 og samhandlingsreformen fra 2012.

Begge har hatt stor betydning for det samlete behandlingstilbudet i norsk helsetjeneste.

Samhandlingsreformen krever et nært samarbeid mellom sykehus og kommunehelsetjeneste for å lykkes, men like viktig er samhandlingen mellom fastlegene og pleie- og omsorgstjenestene i kommunene. Et godt samarbeid vil bidra til å redusere antallet overliggere i sykehus (se faktaboks).

\section{OVERLIGGER}

Utskrivningsklare pasienter som er for syke til å reise rett hjem, blir liggende på sykehus hvis det ikke er ledig korttidsplass eller sykehjemsplass. 


\section{Ulikt i kommuner}

Min undersøkelse fra Østfold i 2014 handler om resultatene av samhandlingsreformen. Den viser at effekten og resultatene varierer fra kommune til kommune. Dette betyr at innbyggernes helsetjeneste varierer med bosted, noe som ikke har vært hensikten med reformene, og som representerer en trussel mot likhetsprinsippet i den norske velferdsstaten.

Undersøkelsen viser også at resultatene er best i mindre kommuner (1). Årsaken er at fastleger og fagfolkene i pleie- og omsorgstjenesten har ulik grad av samhandling. Dessuten er rammebetingelsene for samhandlingen bedre tilrettelagt i slike kommuner.

Det er derfor interessant å se på hvilke utfordringer som disse tjenestene møter i den praktiske hverdagen, og hvordan ulik kommunestørrelse påvirker tjenesteproduksjonen.

De spørsmålene jeg ønsker å få besvart, er følgende:

- Hva betyr kommunestørrelse, fastlegedekning, sykehjemsdekning og forekomst av pleietrengende hjemmeværende eldre for forekomsten av overliggere i sykehus?

- Hvor stor er variasjonen mellom kommunene?

- Hva er de mest sannsynlige forklaringene på denne variasjonen?

Ovennevnte undersøkelse er spesielt viktig fordi den norske regjeringen i 2014 kom med stortingsmeldingen «Fremtidens primærhelsetjeneste - nærhet og helhet», der det står følgende: «Regjeringen vil skape en sammenhengende helse- og omsorgstjeneste med helsepersonell som arbeider i flerfaglige team. Dette vil kreve økt kompetanse og bedre ledelse.» (2) Det burde også stått «bedre samarbeid i primærhelsetjenesten».

\section{Datamateriale og metode}

Østfold er et folkerikt og geografisk lite fylke med 18 kommuner. Bare 17 er med i undersøkelsen siden Rømskog kommune sokner til sykehusene i Akershus. Min undersøkelse omfatter alle overliggere i sykehus i 2014 fordelt på hjemkommune. Materialet inneholder også data for samtlige fastlegeårsverk og sykehjemsdekning. Siden 17 kommuner kan gi et noe uoversiktlig bilde av situasjonen, og siden kommunestørrelse er hovedtemaet for undersøkelsen, er materialet inndelt i tre kommunegrupper:

- kommuner med over 20000 innbyggere

- kommuner med 3000-20 000 innbyggere

- kommuner med mindre enn 3000 innbyggere 


\section{Pasientutveksling}

Tabell 1 viser betydelige kommuneforskjeller når kommunene inndeles etter størrelse, legedekning og behandlingstilbud for pleie og omsorg. En hovedkonklusjon er at små kommuner har klart seg best når det gjelder å ta raskt imot utskrivningsklare pasienter i sykehus. Etter tre år med samhandlingsreformen er mønsteret tydelig: De store kommunene har over dobbelt så høy forekomst av overliggere som de små kommunene, mens mellomstore kommuner kommer i en mellomstilling.

Tabell 1. Oversikt over kommunegruppenes antall fastleger, fastlegedekning og dekning av sykehjemsplasser

\begin{tabular}{|c|c|c|c|c|c|}
\hline $\begin{array}{l}\text { Kommune- } \\
\text { typer }\end{array}$ & $\begin{array}{l}\text { Gj.sn. antall } \\
\text { fastlegeårs- } \\
\text { verk til kura- } \\
\text { tive tjenester }\end{array}$ & $\begin{array}{l}\text { Inn- } \\
\text { byggere } \\
\text { per } \\
\text { fastlege }\end{array}$ & $\begin{array}{l}\text { Over- } \\
\text { ligger- } \\
\text { dager }\end{array}$ & $\begin{array}{l}\text { Dekning av } \\
\text { sykehjems- } \\
\text { plasser per } \\
100 \text { som er } \\
\geq 80 \text { år }\end{array}$ & $\begin{array}{l}\text { Dekning av } \\
\text { korttidsplas- } \\
\text { ser i sykehjem } \\
\text { per } 100 \text { som } \\
\text { er } \geq 80 \text { år }\end{array}$ \\
\hline $\begin{array}{l}\text { Mindre } \\
\text { kommuner }\end{array}$ & 3,1 & 717 & 7,4 & 15 & 22,9 \\
\hline $\begin{array}{l}\text { Mellomstore } \\
\text { kommuner }\end{array}$ & 7,2 & 1076 & 10,2 & 16,3 & 20,1 \\
\hline $\begin{array}{l}\text { Større } \\
\text { kommuner }\end{array}$ & 39,8 & 1085 & 16,9 & 20,5 & 15,1 \\
\hline
\end{tabular}

Disse forskjellene trenger faglige forklaringer for å få en bedre forståelse av situasjonen og gi mulighet til å mestre utfordringene og forbedre tjenestene. Det trengs også empiriske data for pasientstrømmene mellom sykehus og kommunehelsetjeneste slik at potensialet for forbedring blir tydeliggjort. Data fra sykehusene viser at for cirka 10 prosent av alle utskrivninger går det ut melding fra sykehusene til hjemkommunen om at pasienten er utskrivningsklar. I de fleste tilfellene tar kommunen imot disse pasientene uten fristbrudd. Imidlertid tar de ikke imot alle, noe som resulterte i 2027 overliggerdøgn i sykehus i 2014 for pasienter bosatt i Østfold (1).

\section{Ulik mottakskapasitet}

Kommunene har en begrenset mottakskapasitet på kort varsel, noe som påvirker pasientstrømmen. Begrensningen skyldes størrelsen på to faktorer:

- ledige plasser i sykehjem

- ledig kapasitet i behandlingsapparatet i hjemmetjenestene og samarbeidet med fastlegen til disse pasientene 
Mottakskapasiteten på sykehjem avhenger av hvordan

korttidsplassene brukes, siden langtidsplassene er belagt med pasienter med lange liggetider. Liggetiden i korttidsplassene er vanligvis to til tre uker. For å kunne opprettholde en tilstrekkelig god sirkulasjon, må sykehjemmet ha et godt samarbeid med hjemmetjenestene og fastlegene, slik at disse pasientene ikke blir liggende og blokkere korttidsplasser.

\section{三 «De store kommunene har over dobbelt så høy forekomst av overliggere som de små kommunene.»}

Dermed blir mottakskapasiteten i hjemmetjenestene og hos fastlegene avgjørende på to måter. For det første må tjenestene være godt ledet og tilstrekkelig bemannet. For det andre må fastlegene prioritere de utskrivningsklare pasientene og samarbeide med fagpersonalet på pleiesiden.

\section{Fastlegenes kapasitet}

Etter at samhandlingsreformen ble innført i 2012, er behandlingen blitt faglig mer krevende siden det er krav både til kort responstid og til økt medisinsk og pleiemessig kompetanse. Dette skyldes at de utskrivningsklare pasientene som nå skrives ut, er sykere og mer ressurskrevende enn før. Det stiller større krav til legenes faglige kunnskaper og deres tilgjengelighet for denne pasientgruppen i vanlig arbeidstid.

Det er tydelig at suksesskriteriet for kommunene etter 2012 er en faglig opprustet og tilstrekkelig dimensjonert hjemmetjeneste som skal betjene utskrivninger fra sykehus på kort varsel. I tillegg skal den sørge for at utskrivninger fra korttidsplassene i kommunen skjer til avtalt tid. Dette vil pleietjenestene ikke klare uten et nært samarbeid med pasientenes fastlege.

\section{Mulige årsaker}

Tabell 1 inneholder tilstrekkelige data til å kunne analysere de mulige årsakene til at mindre kommuner i Østfold klarer seg bedre enn store kommuner.

Første skritt i analysen er å se på driften av sykehjemmene, som er en viktig faktor for pasientstrømmen av utskrivningsklare pasienter. Tabellen viser at sykehjemskapasiteten er best utbygd i de mindre kommunene, og dekningen av korttidsplasser er høyere. Konklusjonen blir derfor at dekning av korttidsplasser synes å kunne forklare en del av kommuneforskjellene når det gjelder forekomst av overliggere i sykehus. 
Neste skritt er å analysere den andre faktoren, som er bemanning og drift av pleie- og omsorgstjenestene og samarbeidet med fastlegene om felles pasienter. Som beskrevet ovenfor er denne faktoren helt sentral, og hjemmetjenestene og fastlegene har to parallelle oppgaver. De skal ta imot ferdigbehandlete sykehuspasienter direkte fra sykehus og samhandle med sykehjemmene ved å ta imot korttidspasienter fra sykehjemmene til avtalt tid.

\section{Fastlegeordningen}

Det er viktig å kartlegge hvordan fastlegeordningen fra 2001 fungerte i kommunene i Østfold i 2014. Alle kommunene har løst behandlingsbehovet for de kurative legetjenestene gjennom avtaler med selvstendige næringsdrivende leger, det vil si at de ikke er kommunalt ansatte med linjeledelse. Dette er i motsetning til de kommunale samarbeidspartnerne, som er sykepleiere og hjelpepleiere som ledes etter linjelederprinsippet.

Sentralt i fastlegeordningen er at alle legene har en pasientliste som de har et spesielt ansvar for i vanlig arbeidstid. I Østfold er gjennomsnittlig listelengde cirka 1000 personer per fastlege. De fleste av disse pasientene er relativt friske, og et fåtall er pleietrengende. I 2014 fantes det cirka 6500 pleietrengende brukere i hjemmetjenestene i Østfold. Det er denne pasientgruppen som er interessant i samhandlingsanalysen min.

Hvis man fordeler alle de pleietrengende pasientene på de 225 kurative årsverkene til fastlegene i Østfold, vil i gjennomsnitt cirka 30 av listepasientene være pleiepasienter. Tre prosent av personene på lista, altså 30 av 1000, er viktige for samhandlingsreformen og samarbeidet med hjemmetjenestene. Disse relativt få listepasientene befinner seg til enhver tid i en av tre ulike behandlingssituasjoner: De er enten innlagt i sykehus, i korttidsplass i sykehjem eller hjemmeboende med kommunale pleie- og omsorgstjenester, og de har sin fastlege.

\section{Dyrt med overliggere}

Det viktige spørsmålet er dermed: Hvordan kan kommunene lede de næringsdrivende fastlegene på en slik måte at de vil prioritere de oppgavene som kommunen anser som viktige? Et eksempel er rask oppfølging av de pleietrengende pasientene i hjemmetjenestene eller i sykehus, det vil si de som er potensielle overliggere.

\section{«Kommuner med mange overliggerdøgn blir straffet hardt rent økonomisk.»}


Etter fem års drift ble fastlegeordningen evaluert av Norsk forskningsråd. Rapporten fastslår følgende om den kommunale styringen av pasientstrømmen fra sykehus til kommune: «[Den] er avhengig av et godt samarbeid og dialog med fastlegene. Sentrale og individuelle avtaler er en type 'relasjonelle kontakter' som kjennetegnes av at partene har en felles interesse av å opprettholde et langsiktig forhold, og at det legges liten vekt på detaljregulering av plikter og rettigheter. Dette kan være et problem i konfliktsituasjoner. Minimumskravene til kommunal styring av legetjenesten er ganske små, og de fleste kommuner har relativt små styringsambisjoner, de er stort sett tilfreds med hvordan legetjenesten fungerer.» (3, s. 13)

Dette kan imidlertid ha endret seg noe etter at samhandlingsreformen ble innført, i og med at kommuner med mange overliggerdøgn blir straffet hardt rent økonomisk med 4000 kroner per overliggerdøgn.

\section{Motstridende krav}

Når det gjelder den kommunale ledelsen av fastlegenes praksis, er det i tillegg en kompliserende faktor som skyldes den tekniske og økonomiske organiseringen av praksisen til de næringsdrivende fastlegene. De aller fleste har sluttet seg til et privat legesenter som vanligvis er organisert som et aksjeselskap med privatøkonomiske mål. Dette betyr at legen kan komme i en lojalitetskonflikt mellom sin reelle arbeidsgiver, som er aksjeselskapet, og kommunen, som er oppdragsgiveren og avtalepartneren.

Det er ingen økonomiske insentiver i legenes takstsystem, «normaltariffen», til å prioritere behandling av de pleietrengende pasientene på legens liste, og til å samarbeide med hjemmetjenestene. I tillegg blir legearbeidet for de pleietrengende pasientene vanligvis mer tidkrevende og komplisert, både når det gjelder akutte og kroniske medisinske problemstillinger og når det gjelder fastlegens tilgjengelighet for pasient og samarbeidspartnere i hjemmetjenesten.

En hovedkonklusjon blir derfor at de næringsdrivende fastlegene har fått en mer sårbar og problematisk rolle etter at samhandlingsreformen ble operativ. Dette skyldes motstridende økonomiske krav til prioriteringer og overordnet ledelse og vil kunne resultere i betydelige utgifter for kommunene, påført av overliggende pasienter i sykehus.

\section{Kommunestørrelse avgjør?}


Faktaene og analysen nevnt over er generelle. Det som imidlertid er hensikten med denne undersøkelsen, er å se nærmere på dataene i tabell 1. Jeg ønsket å få svar på om kommunestørrelse har betydning for de næringsdrivende legenes rolle som samhandlere med fagpersonalet både i sykehus og kommune.

Tabell 1 synliggjør to viktige forhold:

- tjenestelokalisering

- legedekning

\section{Tjenestelokalisering}

I de større kommunene var det i 2014 i gjennomsnitt nærmere 40 legeårsverk som var øremerket kurative tjenester. I de mindre kommunene var det kun tre slike årsverk i gjennomsnitt.

For organiseringen i private legesentre gir dette to helt ulike virkeligheter. I store kommuner med større «marked» innbyr denne situasjonen til stordriftsfordeler i legesentrene, som har opptil seks-sju legeårsverk. Dette utløser større økonomiske utfordringer og et betydelig arbeidsgiveransvar. Disse legene blir bundet opp til å måtte være til stede fysisk på senteret i vanlig arbeidstid. Økonomisk sett vil dette være mest inntektsbringende både for den enkelte fastlegen og for legesenteret. Det blir mindre tid til sykebesøk, samarbeidsmøter i pasientens hjem eller andre steder, og mindre utadrettet medisinsk praksis.

I små kommuner vil denne situasjonen sjelden være like aktuell. Legesenteret og hjemmetjenestene ligger ofte i nærheten. Denne nærheten fremmer et godt, uformelt samarbeidsmiljø med positive faglige relasjoner mellom legene og fagpersonene $\mathrm{i}$ hjemmetjenesten. Legene vil dermed gjerne strekke seg lenger for å oppfylle hjemmetjenestens faglige forventninger.

\section{三 «Det var hele 50 prosent bedre legedekning i de små kommunene.»}

I store kommuner er det ofte flere baser eller avdelinger for hjemmetjenestene og flere legesentre med geografisk spredning i kommunen. Nettverksarbeidet blir derfor vanskeligere å få til, og relasjonene preges av avstanden.

Konklusjonen er at det tverrfaglige samarbeidet i små kommuner gir bedre muligheter for positiv samhandling. At det i de fire minste kommunene i Østfold ikke var noen overliggere i hele 2014, er en indikasjon på dette.

\section{Legedekning}


Tabellen viser at legedekningen var bedre i de mindre kommunene. Gjennomsnittlig antall innbyggere per kurativt legeårsverk var 717 i de minste kommunene, som hadde under 3000 innbyggere. I kommunene som hadde over 3000 innbyggere i 2014, var det gjennomsnittlige tallet 1080. Dette betyr at det var hele 50 prosent bedre legedekning i de små kommunene sammenliknet med de øvrige kommunene.

Konklusjonen her er at med en kortere liste vil andelen pleietrengende pasienter utgjøre en større andel av listepasientene enn i større kommuner. Kortere liste vil gi bedre tid til hver enkelt pasient og til tverrfaglig samhandling med den øvrige delen av helsetjenesten i kommunen. Samtidig gir lange lister større inntjening til legesenteret og til hver enkelt lege. Totalt sett vil dette prege samhandlingen med resten av den kommunale helsetjenesten, noe som kan medføre et økonomisk tap for kommunen i form av høyere utgifter på grunn av overliggere.

\section{Fire kommuner avviker}

I alt 13 av de 17 Østfold-kommunene har tall og resultater som passer helt med det mønsteret som er beskrevet i denne artikkelen. Hva så med de fire kommunene som er avvikere?

To av disse kommunene befant seg i gruppen med mindre enn 3000 innbyggere. De hadde i gjennomsnitt 2285 innbyggere og 26 overliggerdøgn i sykehus per 100 innbyggere som var 80 år og eldre. Det vil si en betydelig høyere forekomst av overliggere enn for gruppen av større kommuner (se tabell 1). De resterende to kommunene var middels store kommuner. En hadde 4700 innbyggere og 21 overliggerdøgn per 100 innbyggere som var 80 år og eldre.

Den fjerde hadde litt over 10000 innbyggere, men kun 4,5 overliggerdøgn i sykehus mot forventet 10,2, som var gjennomsnittet for denne kommunegruppen.

Det fantes ingen avvik fra det beskrevne mønsteret i de fire største kommunene. Antallet overliggerdøgn styrker det statistiske grunnlaget for konklusjonene i denne artikkelen. En viktig konklusjon er derfor at det ikke er noen automatikk knyttet til kommunestørrelse som forklaringsvariabel. Det er forholdene bak tallene som betyr noe, og tre av de fire avvikerkommunene hadde trolig en svakere ledelse av samhandlingen. Den fjerde utmerket seg sannsynligvis med bedre ledelse og samhandling.

\section{Referanser}


1. Otterstad HK. Samhandler bedre i små kommuner. Sykepleien 2015;12. Tilgjengelig fra:

https://sykepleien.no/forskning/2015/11/overliggere-i-sykehusetter-tre-ar-med-samhandlingsreform. (Nedlastet 27.01.2017).

2. Meld. St. 26 (2014-2015). Fremtidens primærhelsetjeneste nærhet og helhet. Tilgjengelig

fra: https://www.regjeringen.no/no/aktuelt/en-helhetlig-helse-og-

omsorgstjeneste/id2410471/. (Nedlastet 01.02.2017).

3. Norges forskningsråd. Evaluering av fastlegereformen 2001-

2005. Tilgjengelig fra:

http://www.forskningsradet.no/no/Publikasjon/Evaluering_av_fastlegereformen_20012005/11377443006488?

langno. (Nedlastet 26.01.2017). 